\title{
Identification of Sex from Carotid Canal in South Indian Population
}

\author{
Makandar UK ${ }^{1}$, Jadhav Ashwini², Kulkarni PR ${ }^{3}$ and Patil BG ${ }^{4}$ \\ ${ }^{1}$ Associate Professor in Anatomy, India \\ ${ }^{2}$ Associate professor in Anatomy, Dr VM Government medical college, India \\ ${ }^{3}$ Professor and Head Anatomy department. Government medical college, India \\ ${ }^{4}$ professor in Anatomy Sri BM Patil medical college, India
}

Submission: August 11, 2017; Published: August 30, 2017

*Corresponding author: Makandar UK, Associate Professor in Anatomy, AII India Institute of Medical Sciences, India, Tel: 9341610428;

Email:dr.ukm1991@gmail.com

Abstract

45 male, 30 female non-pathological dried crania were selected for study for sexual dimorphism of carotid canal .Carotid canal diameter was measured by digital vernier caliper. The mean value of diameter of right male carotid canal was $0.89 \mathrm{~cm}(\mathrm{SD}+-0.07)$ was compared with mean value of right female carotid Canal , it was $0.66 \mathrm{~cm}(\mathrm{SD}+-0.22)$ and " $\mathrm{t}$ " test value was 11.8 which was highly significant $\mathrm{P}$ value $(\mathrm{P}<0.01)$.The mean left male carotid canal was $0.72 \mathrm{~cm}$ (SD+-0.09) compared with mean value of diameter of left female carotid canal which was $0.53 \mathrm{~cm}$ (SD+-0.07) and " $\mathrm{t}$ " test value was 9.79 which was highly significant $\mathrm{P}$ value $(\mathrm{P}<0.01)$. This study of south Indian crania is presumed mainly as Dravidian Race [1]. This study of sexual dimorphism will have medico-legal, radiological, anatomical and anthropological importance because marphometric study of mesoderm derivatives is uncertain. Moreover knowledge of diameter of carotid canal is very much important to neurosurgeon because while approaching to Cavernous sinus and base of frontal region of Norma Basal is Internal Carotid Artery is more vulnerable for damage which may cause alarming surgical emergency.

Keywords: - CC - carotid canal, ICA- internal carotid artery, Digital vernier Caliper, South Indian

\section{Introduction}

There are many criteria for sexual diamorphism of crania after puberty such as prominence of superciliary arches, breadth of Foramen magnum, depth of diagastric groove, width of Zygomatic arches, length and breadth of mastoid process but least data is available for sexual dimorphism. As CC is a Greek word means sleep. Greek ancestors thought that, the internal carotid artery, sympathetic nerve plexus, venous plexus transmits through cc bring the sleep [2]. As CC is the large rounded foramen in the basal surface of petrous in front of Jugular foramen which gives passage for ICA. The cc is curved upwards, forwards and medially long axis of the petrous bone and opens in the foramen lacerum [3]. In recent advances of skull surgery, approaches to cavernous sinus and frontal skull base transzygomatic approach through middle skull base since ISA runs inside the temporal bone restricts the surgical procedure. Hence it is mandatory to preserve the ICA .hence if we know the sex we can predict the diameter of ICA [4]. Because in some cranial walls of the cc was found to be very thin hence vulnerable during the surgery around the clival region. Hence attempt was made to study the diameter of CC in crania of both sexes so that approaches to the cavernous sinus may save the ICA. It is also observed that $35 \%$ CC is dehiscence in the typantic cavity reminds otologist the anatomical knowledge of CC and temporal bone [5]. Moreover the study of sexual dimorphism has medicolegal, anthropological and anatomical important as metrical values of mesodermal values are uncertain.

\section{Materials and Methods}

45 male and 30 female non pathological dried crania were selected for study. The crania were available in the department of Anatomy and Forensic medicine department .The diameter of CC was measured by Vernier caliper and t test is applied to compare the obtained value of both sexes statistically.

\section{Observation and Results}

(Table 1) Diameter of right CC of male and female crania was measured. The mean value of male $\mathrm{rt} \mathrm{CC}$ was $0.89 \mathrm{cms}$. (SD + 0.07 ) and female CC diameter was 0.67 (SD+- 0.02)'t' test was 11.8. And $\mathrm{p}$ value was highly significant $\mathrm{p}$ vale $<.01$ 
Table 1: Sexual dimorphism between right carotid canals of male crania with right carotid canal of female crania.

\begin{tabular}{|c|c|c|c|c|}
\hline Sl no & $\begin{array}{c}\text { No of male } \\
\text { crania 45 }\end{array}$ & $\begin{array}{c}\text { No of } \\
\text { female } \\
\text { crania 30 }\end{array}$ & T test & P value \\
\hline Mean value & $\begin{array}{c}0.89 \mathrm{cms} \\
(\mathrm{SD}+0.07)\end{array}$ & $\begin{array}{c}0.67 \\
\left(\mathrm{SD}+{ }_{0} 0.2\right)\end{array}$ & 11.8 & $\mathrm{P}<0.01$ \\
\hline
\end{tabular}

$P$ value is highly significant.

Table 2: Sexual dimorphism between left carotid canals of male with left female carotid canal.

\begin{tabular}{|c|c|c|c|c|}
\hline Sl no & $\begin{array}{c}\text { No of male } \\
\text { crania 45 }\end{array}$ & $\begin{array}{c}\text { No of } \\
\text { female } \\
\text { crania 30 }\end{array}$ & T test & P value \\
\hline Mean value & $\begin{array}{c}0.72 \\
(S D+0.09)\end{array}$ & $\begin{array}{c}0.54 \\
(S D+20.07)\end{array}$ & 9.79 & $\mathrm{P}<0.01$ \\
\hline
\end{tabular}

$P$ value is highly significant

Table 3: Study of sexual dimorphism of CC in previous works.

\begin{tabular}{|c|c|c|c|c|}
\hline & Male crania & & Female crania & \\
\hline Workers with year & Diameter of rt CC & Diameter of lt CC & Diameter of rt CC & Diameter of lt CC \\
\hline Calguner et al. 1997 & $0.65(\mathrm{SD}+0.8)$ & $0.56(\mathrm{SD}+1.0)$ & $0.66(\mathrm{SD}+1.0)$ & $0.63(\mathrm{sd}+1.0)$ \\
\hline AboAoan Mihd 2007 & $0.68\left(\mathrm{SD}+\_0.8\right)$ & $0.56(\mathrm{SD}+0.6)$ & $0.64(\mathrm{SD}+.06)$ & $0.49(\mathrm{SD}+.5)$ \\
\hline Sheikh v 9 and Kulkarni & $0.76(\mathrm{SD}+0.09)$ & $0.75(\mathrm{SD}+0.1)$ & $0.73(\mathrm{SD}+0.1)$ & $0.72\left(\mathrm{SD}+\_0.1\right)$ \\
\hline Chin kulkari & 0.57 & 0.55 & 0.44 & 0.42 \\
\hline Present study & $0.89\left(\mathrm{SD}+\_0.07\right)$ & $0.72(\mathrm{SD}+0.09)$ & $0.67\left(\mathrm{SD}+\_0.01\right)$ & $0.54\left(\mathrm{SD}+\_0.07\right)$ \\
\hline
\end{tabular}

No literature is available in English to confirm these variations between two sexes. The probable reason could be the haemodynamic pressure is more in male crania as compared to female crania [9], moreover haemodynamic pressure on right side of the brain, hence diameter of the right CC are more than left side in both sexes. The increased diameter of male CC than female CC is paedomorphic tendency of human skull [8].

In addition to this hormonal, nutritional, environmental factors may also play vital role for the morphometric development of crania. Moreover skull itself might have become thinner as a result of reduced masticatory musculature and this must have enclosed the way for expansion of cranium to house the bigger brain of male than female [10]. Moreover bone is the most plastic tissue next to blood. Developmentally CC completes its its growth of diameter approximately at the age of 2 years, hence certainly there is continuation roles of genes also [11]. Moreover these crania belonging to South Indian population are presumed as Dravidians. Hence these values represent the regional or ethnic significance.

\section{Summary and Conclusion}

The present study of identification of sex have surgical importance because by knowing these values of diameter,
(Table 2) The diameter of left CC from male and female were measured. The mean value of male left CC was $0.72 \mathrm{cms}(\mathrm{SD}+$ 0.09 ) and female left CC was $0.54 \mathrm{cms}\left(\mathrm{SD}+_{-} 0.07\right)^{\prime} \mathrm{t}$ ' test was 9.79.and $\mathrm{p}$ value was highly significant. $(\mathrm{p}<0.01)$

\section{Discussion}

In the present study the mean value of the diameter of right CC was $.89 \mathrm{cms}(\mathrm{SD}+.07)$ in male crania , and mean value of diameter of female right $\mathrm{CC}$ was $0.67 \mathrm{cms}\left(\mathrm{SD}+_{-} 0.02\right)$. and ' $\mathrm{t}$ 'test value was 11.8 significant $p$ value $(P<0.01)$ and mean value of diameter of left cc in male crania was $0.72 \mathrm{cms}\left(\mathrm{SD}++_{-} 0.09\right)$ and female left CC was $0.54 \mathrm{cms}\left(\mathrm{SD}+_{-} 0.07\right.$ ) and ' $\mathrm{t}$ ' test value was 9.79 with significant $\mathrm{p}$ value $(\mathrm{p}<.01)$ (Table 2 ).

These findings were more or less in agreement with previous studies [6-8] (Table 3). neurosurgeons will be confident and bold to approach Cavernous sinus and frontal region of basal skull. This study will have medico-legal, anthropological, anatomical, regional significance but this study demands further histological, embryological and genetic study because development of norma basalis is more complicated and ambiguous. The exact duration and mechanism of ossification of crania is still unclear. This paper is approved by the Ethical committee of AIMS BG Nagar, 571448, Mandya district.

\section{Acknowledgement}

Authors are grateful to Dr. M G Shivaramu, Principal AIMS BG Nagar for his constant encouragement.

\section{References}

1. Bhasin MK (2006) Genetics of caste and tribes of Indian population of milieu. International Journal of Genitics 6(3): 233-274.

2. Earnest Frazer J (1933) Anatomy of Human Skeleton $3^{\text {rd }}$ edition, J\&A Churchill 40, Gloucester place, portman square publication, London.

3. Lost RJ (1968) Anatomy of basal skull, 6th edition. HK Lewis and company publication London. 89-92.

4. Kawakani K, Kawamooto K, T suji H (1993) Opening of the carotid canal in the skull base surgery, drilling of the carotid triangle. No shikel Geka 21(11): 1013-1019. 
5. Norma de olivera penido, Andrei Borin, Yotoka Fakuda (2005) Microscopic Anatomy of carotid canal and its relations with cochlea and middle Ear. Brazalion J of Otorhinolaryngology 71(4).

6. Berlis A Putz, M schumachar (1992) Direct and CT measurements of canals and foramina of the skull Base. The British J of Radiology 65: 653-661.

7. Ramteerthakar, Ruta N, Umarji N (2012) Study of carotid canal for identification of sex. Medico-legal update 12(1): 110-112

8. Sheikh VG, Kulkarni PR (2014) A study of morphology, morphometry, symmetry and development of external opening of carotid canal with comparison of male, female and fetus. Int J of Anat 2(4): 797-785.

9. Hasebe S, Sanda I, Oita Y (2003) Proximity of carotid canal wall to tympanic membrane, the human Temporal bone study. Larangoscope 113(5): 802-807.

10. Brace (1967) Environment tooth form and size in the Pleistocene. J of Dental research 46(5): 809-816.

11. Quint DJ, Silpergtleit R, Young WC (1992) Absence of carotid canal at skull base. CT Radiology 182(2): 477-481.

\section{Your next submission with Juniper Publishers will reach you the below assets}

- Quality Editorial service

- Swift Peer Review

- Reprints availability

- E-prints Service

- Manuscript Podcast for convenient understanding

- Global attainment for your research

- Manuscript accessibility in different formats ( Pdf, E-pub, Full Text, Audio)

- Unceasing customer service

Track the below URL for one-step submission https://juniperpublishers.com/online-submission.php 